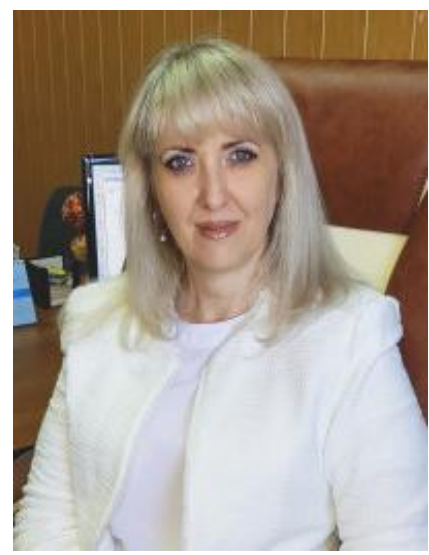

\author{
Наталія Пазюра, \\ доктор педагогічних наук, доцент, \\ завідувач кафредри авіаційної англійської мови, \\ Національний авіаційний університет, (м.Київ, \\ Україна) \\ Nataliya Paziura, \\ Doctor of Science in Pedagogy, associate professor, \\ head of Aviation English Department of National \\ Aviation University \\ (Kyiv, Ukraine) \\ npazyura@ukr.net \\ ORCID ID 0000-0003-1234-7610
}

УДК 811.1181-373.611

\title{
FORMING IMPORTANT COMPETENCES OF ENGLISH TEACHERS IN THE PROCESS OF THEIR PROFESSIONAL TRAINING
}

Abstract. The article presents the results of the analysis of the peculiarities in English teacher training, ensuring highly professional activity of teachers. The purpose and tasks of the study are to characterize the features of the practical formation of important competences of future teachers of the English language in the process of their professional training on a distinguished theoretical basis. Methodology of the study included descriptive methods (research, analysis and description of documents, scientific and educational sources) and a comparative method (identification of general and individual pedagogical patterns). Especially urgent is the question of the updating the contents of education in higher educational institutions according to the principles of personality-oriented approach targeted at development of teachers' personality, their common and professional competence. It is directed at revealing progressive ideas in teachers' professional development. Special attention is paid to the strengthening practical component in curriculum in the process acquirement of theoretical and practical knowledge and skills. The author has shown the necessary competences of a teacher of English: special, methodical, managerial, communicative, creative. The author concluded that it is necessary to study the peculiarities of teaching English in order to increase the effectiveness of training future teachers for professional activities.

Keywords: professional education, English teachers' competence, forms and methods of teaching, constructivism approach, creative teaching.

\section{ФОРМУВАННЯ КОМПЕТЕНТНОСТЕЙ ВЧИТЕЛІВ АНГЛІЙСЬКОЇ МОВИ В ПРОЦЕСІ ЇХНЬОЇ ФАХОВОЇ ПІДГОТОВКИ}

Анотація. Актуальність статті зумовлена розширенням міжнародного співробітництва в різних сферах діяльності під впливом глобалізаційних тенденцій, стрімким розвитком міжнародних ділових контактів. Ці чинники актуалізують володіння іноземною мовою, зазвичай англійською, як засобом міжкультурного спілкування. Мета і завдання дослідження полягають у тому, щоб на визначній теоретичній основі схарактеризувати особливості практичного формування важливих компетенцій майбутніх учителів англійської мови в процесі їх професійної підготовки. Методологія дослідження включала описові методи (дослідження, аналіз та опис документів, наукові та освітні джерела) та порівняльний метод (ідентифікація загальних і окремих педагогічних закономірностей).

Досліджено теоретичні засади підготовки вчителів англійської мови: застосування конструктивістського, комунікативного, студентоцентрованого підходів, що забезпечують студентів можливістю конструювати їхні знання та розвивати навички комунікації у реальній або змодельованій ситуації. Виявлені практичні методи та технології, що сприяють удосконаленню процесу професійної підготовки учителів англійської мови, а саме: проблемно-орієнтоване та автономне навчання, що змушує студентів до пошуку професійної інформації, виконання креативних завдань. Особливо важливим $є$ питання оновлення змісту навчання у закладах вищої освіти відповідно до принципів особистісно-орієнтованого підходу, який націлений на розвиток особистості майбутніх викладачів, їхньої професійної компетентності, саморозвиток. Виявлені необхідні компетентності викладача англійської мови. До них віднесені спеціальна, методична, управлінська, комунікативна, креативна. Підсумком статті $€$ настанова щодо необхідності дослідження особливостей викладання англійської мови 3 метою підвищення ефективності підготовки майбутніх учителів до професійної діяльності.

Ключові слова: професійна освіта, компетентності учителя англійської мови, форми та методи навчання, конструктивістський підхід, креативне навчання. 


\section{INTRODUCTION}

Expansion of European Union results in considerable changes in different spheres of human life, and in the field of education as well. The development of Ukrainian society is marked by the search of the innovative trends in teacher training, and it is stressed in many state documents and legislative acts. The special attention is paid to the problems of professional training of teachers, whose activity should be directed to the harmonious development of every personality, forming in their students ideals, values of modern society, and also to the preparation of rising generation for an active social life.

The English language as the main language of international communication has been in the center of scholars' attention for a long period of time. Its different aspects have been the object of scientific studies. In the result of the researches scientists came to the conclusion about the existence of two approaches to teaching English, which are focused on the special needs of students and improvement of a learner's communicative abilities for his professional performance in foreign language environment. No wonder that nowadays the amount of educational establishments which offer the English language courses is increasing steadily in those countries, where the English is studied as a foreign language. Learning ESP is considered the necessary prerequisite of high professional competitiveness and further promotion [4, p. 1042].

Literature review. Today, in leading Ukrainian scientists' opinion (V. Andriushchenko, P. Beh, I. Ziaziun, V. Kremen, G. Onkovych, and others) the quality of higher education largely depends on university graduating students' language proficiency. More attention is paid to the aspects of studies of a foreign language as a language of professional communication, because in professional development of future specialist professional communication together with professional activity is determining factor of his or her successful career. A number of researchers (Y. Avsiukevich, $O$. Bigych, Y. Degtiariova, T. Karaeva and others) devoted their work to language training of future specialists in one particular sphere of industry. Scholars insist on the importance of innovative techniques in language teaching. Some of them (N. Bibik, D. Bubnova, V. Martyniuk, O. Savchenko, J. Richards and other) consider projects and gamification a good opportunity to combine learning and professional environment. The use of modern multimedia technologies in teaching a foreign language is the object of study such researches as N. Klevtsova, T. Kolesova, O. Tarnapolsky. Main trends in the development of higher pedagogical education and teachers' professional development in different countries were studied by I. Zadorozhna, Yu. Kischenko, A. Parinov (Grait Britain), T. Vakulenko, N. Kozak, A. Turchin (Germany), O. Bocharova, O. Golotyuk, O. Romanenko (France), T. Koshmanova, T. Osadcha, R. Roman, L. Smal'ko T. Chuvakova (USA), I. Kovchina, L. Yurchik (Poland). But special attention should be paid to revealing peculiarities and innovative methods in the area of forming teachers' pedagogical skills.

THE AIM AND TASKS RESEARCH is to work our theoretical basis and characterize peculiarities in practical forming important competences of future English teachers in the process of their professional training. The tasks include analysis of effective methods and English teachers' necessary competences.

RESEARCH METHODS: For our research we used scientific general methods which suggest studying scientific sources. The research methodology included descriptive methods (study, analysis and description of documents, scientific and educational sources) and comparative method (identification of common and distinct pedagogical patterns).

\section{RESEARCH RESULTS}

While studying the questions of pedagogical education in the world, it is possible to come to the conclusion, that structure and contents of education have their own specific features in different countries, but there are four components that are present in the contents of education of future teachers in all countries: general subjects; special subjects; teaching method; pedagogical practice. We consider strengthening practical part to be an important tendency in a block psychological pedagogical disciplines. It is possible to say, that in 90 s years of the last century the value of practical part of curriculum was revised, universities activated the development of researches and strengthened the practically oriented curriculum. Canada, Great Britain and the Netherlands, in the last ten-year period of the last century increased the practical component in curriculum, due to diminishing theoretical one in the contents of education. In Great Britain reforms of pedagogical education took place at the beginning of 1990s, and more than half of time of pedagogical training began to be devoted to practical activity at school. In Hungary, a governmental order to the certification of teachers defined that a not less than $40 \%$ of pedagogical training must be practical. The primary purpose of curriculum in the Netherlands - not only cognitive and emotional development, and yet the development of creative, social, cultural and physical skills. Educational establishments within the limits of their programs, have a right to decide independently what amount of hours and when should be devoted to different subjects in curriculum. Important trend in curriculum in Scotland is training students to a few professions, that is confirmed by certificates. In the conditions of rapid socio-economic growth it gives them possibility to change a profession in the case of necessity.

Besides, schooling meets individual demands too, which means «age, capabilities, possibilities», and is directed to the development of «personality, talents, mental and physical abilities of children and young people, for the fullest realization of their potential». The Scottish system of education assists development of a person's independent thinking, and at the same time provides him possibility to carry out various roles in the conditions of socio-economic changes. But it means responsibility for own studies, healthy way of life, welfare, growth and cultural enriching of society, support of national values and participation in democratic processes. In 2004 the Curriculum of Irreproachability was given out, that determines aims and principles of education for children and young people in age from 3 to 18 . In 
accordance with this document education is development of successful student, self-assured personality, responsible citizen, and effective worker. However the existing system of teacher training does not always provide high quality of training. This problem can be settled by different ways: - more intensive pedagogical practice to get a certificate;

- widening pedagogical qualifying standards for the improvement the quality of the programs to get pedagogical qualification (especially simultaneous programs); - participating junior classes teachers in the mentoring programs with more experienced colleagues [6, p. 121].

According to analyzed material, theoretical basis of language teaching is constructivism approach. Constructivism approach to teaching any subject may be determined as approach that allows students to construct their knowledge and skills by means of practical actions in real-life or simulated environment. Constructivism approach is very effective in English teaching as it doesn't require intentional drilling. With it memorizing occurs subconsciously in the process of creative communication on vocational topics in simulated situations. It is important that in the process of communication students obtain new knowledge and skills. Teaching with constructivism approach is based on learning autonomy and in the case of professional communication in simulated environment this autonomy becomes creative, taking into consideration the fact that professional communication, even simulated, means problem-solving activity. It turns English teaching into problemoriented one that enhances efficiency due to overall students' involvement.

Problem-oriented and autonomous learning forces students to search specialized information, do creative professional tasks. Practical realization of constructivism approach in English teaching is observed in experimental teaching with the use of experimental types of activity, which simulate extra linguistic professional reality. This guarantees functioning learners' target language. In such a way the skills of professional communication are subconsciously constructed in the process of quasi professional experience. Their acquisition is the result of direct involvement in professional communication [8, p. 160]. Thus, experimental learning with simulated situations is the basis for constructivism approach. Others widely spread approaches in English teaching are functional and communicative approaches, which appeared as respond to needs and which, in fact, were the basis for modern Common European Framework of Reference for languages (CEFR) [5, p.151]. With complex character of language in mind it is important to determine necessary competences of future English teachers. We should bear in mind that language teaching is a brunch of scientific knowledge with its own methodology and techniques that are unknown for industry specialists. Future English teachers must have Functional academic literacy (lexical information processing, preparation of presentations etc), their main skill, that is necessary for language teacher activity. That is why due to special training for these functions English teacher can more efficient [4, p. 1054].

Quite logical in this context is the question about necessary for English teacher competences. According to some scientists English teachers should have learning skills as they continuously have to acquire new knowledge. In this process they take up new occupation as a novice in which they have to learn fast.

English teacher should be a good communicator and establish good relations with students who inform him about news in the industry. And in the course of a lesson the teacher should be ready for unexpected questions that can interfere with the planned scenario. On the other hand it is students who can help find the correct answer and offer their explanations. Communication and cooperation skills are necessary for modification of the course design according to students' needs [3, p. 26]. English teacher needs multitask solving skills as he has to do several things simultaneously, like react to unexpected situations, learn new information and offer explanations etc. Such skills are usual for any teacher (observation, supervision, assessment of students' activity). But ESP teacher besides it often has to change the planned course of the lesson, find more appropriate examples, control students' understanding and check his own understanding the material that is being taught [2, p.87].

It is necessary to stress that in ESP teaching students' assessment is somewhat different from usual one. Traditionally EAP teachers use tests, exams, tasks, control papers. In case with ESP learners who work they can be assessed by a number of people: ESP teacher, learner himself (for example in communication with foreign partners), supervisor [2, p.91].

English teacher should be a good presenter to show learning material in a structured way, to be able to explain differences in languages, in speech patterns and lexical units. English teacher should skillfully choose forms and methods of teaching, and even body language, manner of speech are considered to be important factors in teaching process. It is relevant to general English as well, but fir English teacher it is important to make most of it, adding information and communication technologies, hand out materials for better illustration of key points of the lesson [2, p. 90].

Besides, English teacher should be a problem-shooter and be able to offer quick solution to a problem (for example, to name another modification of a product, to know faults in models etc in case with ESP teachers). There is even an idea that content of training should be designed from the engineer's point of view.

English teacher should be a good manager to manage unexpected situations in a classroom and to define the most important skills for students. On this point ESP and EAP teachers' functions are similar, but in case with ESP teacher probability of unexpected situations is higher as there are much more information in professional sphere in which ESP teacher may not knowledgeable enough. These very situations need his managerial skills to modify planned course of a lesson.

Among other essential skills for English teacher scientists mention his ability to create learning environment. Creativity of English teacher is considered as his efforts to bring up creative thinking. It is an agreed point that in order to become English teacher on should always search motivation, inspiration and creative techniques appropriate for 
certain learners. Attempt to teach creatively is more suitable for ESP lessons and unlike traditional and widely used techniques can not destroy desire to learn [7, p. 175].

More frequent use of ICT, creation of interactive atmosphere, students' creativity development, an inclusive character of such lessons confirms the statement about efficiency of creative teaching. Among its disadvantages such things are mentioned as unexpected character, necessity of diligent preparation and detailed planning. But in spite of these disadvantages creative teaching remains the most challenging approach in ESP teaching. As English is often learned by adults, creative teaching opens opportunities for discussions, expression of personal points of view, introduction of new ideas, values etc. It also widens limits of free and objective interaction and in such a way enriches all participants with new ideas [7, p. 176].

In creative teaching English teachers often use such technique as supposition (certain variants are offered for a situation, negative brainstorming is conducted) which integrates scientific learning with interesting narrative that encourages learners to study scientific details connected with unreal situation. In this case learners get skills of problem solving and deductive reasoning. Role playing technique allows students to use practically learned material and gives opportunity to step in the shoes of main characters of the imaginary story.

\section{CONCUSSION AND PROSPECTS FOR FURTHER RESEARCH}

Thus, English has a complicated character and needs further researches about its peculiarities for better teaching results. As English teaching is designed according to professional learners' needs, it makes use of most effective approaches, methods and techniques. Creative teaching needs proper preparation as English teaching suggests deep analysis of the subject a teacher does not always know. The most useful skills are managerial skills and innovative and creative approach especially on the level of problem presentation for raising students' interest and their motivation. Further researchers should be conducted in the sphere of modern methods aimed at improvement language proficiency level of future specialist.

\section{REFERENCES}

[1] Braud, V., Millot, P., Sarré, C., \& Wozniak, S. Quelles conceptions de la maîtrise de l'anglais en contexte professionnel ? Vers une définition de la compétence en anglais de specialite. Melanges CRAPEL, 2017. N. 37, P. 13-44.

[2] Karen Chung-chien Chang. From EAP to ESP: A teacher's identity development. Taiwan Journal of TESOL. 2017. Vol. 14.2, P. 71-100.

[3] Momtazur, R. English for Specific Purposes (ESP): A Holistic Review. Universal Journal of Educational Research. 2015. N 3(1). P. 2431.

[4] Mousavi, S., Gholami, J., Sarkhosh, M. Key Stakeholders' Attitudes in ESP Courses on the Right Teachers. International Journal of Instruction. 2018. Vol.12, No.1, P. $1041-1058$.

[5] McKay, S., Munby, J. Communicative syllabus design. The modern language journal. 1980. N 64(1). P. 151-157.

[6] Pazyura, N. Progressive ideas in updating teacher training in developed countries. Proceedings of the National Aviation University. 2015. N 2(63): 120-123

[7] Petkovska, V. Teaching Creatively In ESP. Journal of Education and Practice. 2015. Vol.6, No.17. P. 172-176.

[8] Tarnopolsky, O. Idea Sharing: Professionalizing ESP Teaching to University Students through Modeling Professional Interaction in ESP Classrooms. PASAA. 2015. v. 50. P. 155-172. 